\title{
O ASSÉDIO PROCESSUAL: UMA ANÁLISE A PARTIR DO IMPERATIVO CATEGÓRICO KANTIANO
}

\section{Guilherme Carneiro de Rezende ${ }^{1}$ Paulo Henrique Helene ${ }^{2}$}

\begin{abstract}
Resumo:
O Código de Processo Civil estabeleceu já em seu dispositivo inaugural uma interlocução do processo com a Constituição Federal. Reafirmou este como instrumento de cidadania e democracia participativa e, justamente por isso, revelou o seu compromisso com a ética. Uma ética que não independe de agências externas para se consolidar, senão do próprio indivíduo, baseado na máxima Kantiana. O Digesto enumerou pontualmente algumas situações violadoras dessa ética, trazendo, entretanto, a cláusula geral da boa-fé objetiva, capaz de tutelar um número indefinido de situações, inclusive o abuso processual, que se pretende conceituar, mediante revisão bibliográfica e situar na práxis forense.
\end{abstract}

Palavras-chave: Processo. Ética. Boa-fé. Abuso processual.

\section{PROCEDURAL HARASSMENT: AN ANALYSIS FROM THE KANTIAN CATEGORICAL IMPERATIVE}

\begin{abstract}
:
The Civil Procedure Code already established in its inaugural provision an interlocution of the process with the Federal Constitution. He reaffirmed this as an instrument of citizenship and participatory democracy and, just for that reason, revealed his commitment to ethics. An ethics that does not depend on external agencies for consolidation, but on the individual himself, based on the Kantian maxim. Digesto punctually lists some situations that violate this ethics, bringing, however, a general clause of objective good faith, capable of protecting an indefinite number of situations, including procedural abuse, if conceptualizing, using the bibliographic review and the forensic predictive situation.
\end{abstract}

Keywords: Process. Ethic. Good faith. Procedural abuse.

\section{INTRODUÇÃO}

O ordenamento jurídico brasileiro é composto por uma série de textos jurídicos que consagram em seu bojo uma hierarquização de valores. Aliás, o Poder Legislativo é pródigo na

\footnotetext{
${ }^{1}$ Mestrando em Direito pela Universidade do Vale do Rio dos Sinos (UNISINOS). Especialista. Professor no Centro Universitário FAG e na Escola da Magistratura do Paraná. Promotor de Justiça.

${ }^{2}$ Mestrando em Direito Público pela Universidade do Vale do Rio dos Sinos (UNISINOS). Especialista em Direito Penal, Processual Penal e Tributário, com formação complementar em Direito Penal e Processo Penal Alemão, Europeu e Internacional pela Georg-August-Universität Göttingen (GAUG). Professor no Centro Universitário FAG. Servidor do TJPR.
} 
edição de normas para a tutela das mais variadas situações, sendo, muitas das vezes, impulsionado pelo clamor social, advindo de acontecimentos notórios.

Cediço, entretanto, que a singela positivação de direitos não é suficiente para a sua efetiva garantia, surgindo o Poder Judiciário como verdadeiro bastião à salvaguarda de interesses. E o faz após a provocação, por meio de importante garantia fundamental consistente no acesso à justiça.

Esse acesso não se encerra na simples provocação, por meio de um direito de petição. Trata-se de direito autônomo, pelo qual o interessado provoca o Judiciário em busca de um provimento, que, naturalmente, lhe deve ser entregue de forma justa, célere e eficaz.

Essas premissas estão fincadas no artigo $4^{\circ}$, do Código de Processo Civil, valendo registro, demais disso, que a razoável duração do processo foi erigida à categoria de direito fundamental, com a edição da emenda constitucional n. 45.

O Conselho Nacional de Justiça, entretanto, apontou em diagnóstico realizado sobre os dados da justiça brasileira, conforme o editoral do "justiça em números," ano de 2019, que o tempo médio de processo pendente na fase de execução, particularmente nas Justiças Estadual e Federal, é de 8 anos e 1 mês e 6 anos e 2 meses, respectivamente. Isso sem se falar na fase de conhecimento que lhe antecede, que segundo dados do CNJ dura, naquela 4 anos e 6 meses e nesta 3 anos e 7 meses, afora a fase recursal.

Está-se, aparentemente, muito longe de um processo que dura tempo razoável.

As causas para esta demora podem ser atribuídas a diversos fatores, que variam desde as precárias situações dos Juízos, muitas das vezes desprovidos de estrutura suficiente ao atendimento da demanda, à sobrecarga de trabalho dos magistrados, à cultura demandista brasileira e, não menos, à violação de preceitos éticos que às vezes retardam o encerramento da prestação estatal.

Isso naturalmente reduz o índice de percepção da Justiça brasileira, que segundo relatório ICJ Brasil, da Fundação Getúlio Vargas, elaborada no $1^{\circ}$ Semestre do ano de 2017, de 2013 para 2017 caiu 10 pontos percentuais, estacionando no patamar de $24 \%$.

Dentre as causas já referidas há que se sublinhar em especial a violação aos preceitos éticos, mais pontualmente o abuso processual, que aqui será analisado sob a perspectiva Kantiana.

A análise do temário não pode prescindir de um escorço sobre o a transição entre os Códigos Buzaid e o novel Código de Processo Civil, em especial pelo seu declarado perfil de 
conformação constitucional, do acesso e do descesso à Justiça, e da ética sob a perspectiva Kantiana, bem assim da boa-fé.

O abuso processual, seja como categoria concebida a partir do abuso do direito, tradicional da doutrina civilista, seja como decorrência das funções restritiva e interpretativa da boa-fé, trata de uma realidade cada vez mais frequente, e que vem sendo combalida pelos tribunais brasileiros, contribuindo para um giro ético no trato do processo, enquanto ferramenta à implementação de direitos.

\section{O NEOCONSTITUCIONALISMO}

O termo pós quer, ou melhor pretende, significar novo. Novo na perspectiva de se superar paradigmas e referenciais descobertos pela ciência e que a acompanharam durante décadas ou mesmo séculos.

Mais particularmente no que diz respeito ao direito, há que se reconhecer que o contexto histórico do pós-guerra foi campo fértil ao surgimento de um novo ponto de partida para todas as relações: a pessoa humana.

As barbaridades cometidas pelos regimes nazifascistas, parte delas catalogadas em livros de história e documentários, e inclusive julgadas pelo Tribunal de Nuermberg, marcaram a história da humanidade e contribuíram ao modelo normativo que se tem hoje, tanto na Europa região mais afetada pelo influxo do totalitarismo -, quanto nos demais continentes.

O neoconstitucionalismo, e de sorte o neoprocessualismo, no que diz respeito ao marco filosófico, rompem com a ideia do positivismo, cuja crise se anunciou ainda sob a égide destes regimes, que buscavam justificar atrocidades cometidas com base no legalismo e na estrita obediência à lei.

$\mathrm{Na}$ era moderna (do positivismo), imperava a razão, que era capaz de produzir um potencial ilimitado de conhecimento, tornando (ou pretendendo tornar) tudo previsível. Havia um culto à ordem, à norma, sem qualquer consideração em torno da moral e do justo. $\mathrm{O}$ ordenamento jurídico era (ou ao menos pretendia ser) completo e não se reconhecia a normatividade dos princípios.

Este modelo, entretanto, se viu mergulhado em crise na era pós-moderna, sobretudo diante da concepção de que a ciência estava submetida a condicionantes contextuais, sofria o inevitável influxo da história. Era, pois, mutável, contextualizada e fragmentária. 
Com o giro crítico do pós-modernismo, percebeu-se que não há como produzir uma ciência como linguagem neutra, depurada, matematicamente precisa. Nota-se que ela sofre a influencia da cultura simbólica, da psicanálise e das relações de produção.

O próprio direito também sofre com esta crise, pois "ele deixa de se respaldar na neutralidade do sujeito, na transparência do objeto e na pureza da linguagem para dar destaque à dimensão política do sujeito, à complexidade do objeto e ao caráter pragmático da linguagem." (GOMES, 2010, p. 195)

Conceitos tradicionais são ressignificados, já que as barreiras da soberania ruem diante do globalismo, percebe-se que a lei recebe contaminação de forças políticas, sendo passível de lacunas e equívocos, e a própria democracia representativa enfrenta duras críticas, diante das crises de legitimidade dos Poderes da República, por conta de tantos e tantos escândalos.

Basta ver, por exemplo, as atrocidades cometidas durante o período do holocausto, tudo em nome de uma obediência irrestrita à lei (princípio da legalidade); ou o contexto fático da edição de textos normativos, em que a mola propulsora dos representantes eleitos pouco ou nunca é o interesse público, mas sim um interesse setorizado, ou pior, econômico-patrimonial (daqueles representantes); textos normativos incapazes de resistir aos anos, sendo corroídos pela marcha do tempo, pela tecnologia, pela globalização, enfim.

No plano teórico, BARROSO (2005) anuncia três transformações no direito, que são a) o reconhecimento de força normativa à Constituição; b) a expansão da jurisdição constitucional; c) o desenvolvimento de uma nova dogmática da interpretação constitucional.

Sobre a força normativa da Constituição, deixa ela de ser um mero documento de intenções e assume a feição de norma, cuja obediência se fazia como imperativo.

HESSE (1998, p. 51) sublinha que:

Conteúdos que são realizados em contradição com elas [normas constitucionais] também não podem, por isso ser 'realidade constitucional', isto é, Constituição realizada, em todo o caso, então não, se o conceito deve conter mais que uma irreflexão.

Justamente como forma de garantir essa supremacia constitucional, buscando resguardar sempre a compatibilidade das normas infraconstitucionais com a Lei Maior, que foram aprimorados mecanismos de controle de constitucionalidade, seja pela via concentrada, seja pela via difusa.

Isso permitiu, inclusive recuperar, por meio da atuação do Poder Judiciário, a democracia participativa (diante da crise da democracia representativa), conforme ensina 
MITIDIERO (2007, p. 26/27):

(...) o controle difuso de constitucionalidade é o mais democrático, sendo, dessarte, o mais impregnado de legitimidade. Deveras, ao lado da democracia representativa, ideal do próprio Estado Moderno, ganha força a democracia participativa, própria do Estado Contemporâneo, verdadeiro direito de quarta dimensão, que incentiva os cidadãos a participarem diretamente no manejo de poder do Estado, dando legitimidade à normatividade pela via da hermenêutica.

Quanto à interpretação, o novel modelo traz balizas próprias, sem, contudo, abandonar os métodos tradicionais (critério hierárquico, temporal e o espacial).

A hermenêutica tradicional baseava-se em duas premissas, que eram o papel da norma e o papel do juiz. Como ela se finca no positivismo, em que o ordenamento se pretende completo e acabado, por meio da lei, a atividade do aplicador da norma se resumiria à subsunção.

No período pós-positivista, o legislador faz uso de cláusulas gerais ou conceitos jurídicos indeterminados, até porque, na linha do que sustenta $\operatorname{HESSE}$ (1998, p. 40),

(...) em cruzamento com tais razões especiais e mais além delas, deve a Constituição, enfim, ficar imperfeita e incompleta, porque a vida, que ela quer ordenar, é vida histórica e, por causa disso, está sujeita a alterações históricas.

Reconhece-se, ademais, a força normativa dos princípios e a atividade criativa do juiz, que se torna "co-participante do processo de criação do Direito, completando o trabalho do legislador, ao fazer valorações de sentido para as cláusulas abertas e ao realizar escolhas entre soluções possíveis" (BARROSO, 2005).

O Judiciário assume um protagonismo, pois

(...) além da previsão formal de direitos fundamentais, é indispensável desenvolver meios processuais que permitam que o Estado-juiz assegure, efetivamente, a tutela de direitos.

A inércia do Poder Público ao aplicar e tornar efetiva a Lei Fundamental exige a atuação segura do Poder Judiciário, cujo dever é fazer respeitar a Constituição e as Leis.

(CAMBI, p. 372)

\section{O NEOPROCESSUALISMO}

O novo Código de Processo Civil, consagrado na Lei 13.105/2015, em vigor desde o ano de 2016, veio para substituir o vetusto Código Buzaid, editado ainda no século passado, na década de 70.

O diploma anterior, editado para fazer frente às prescrições do também já arcaico 
Código Bevilaqua, datado de 1916, era marcado por uma tradição individualista, voluntarista e patrimonialista.

Isto porque, concebido no seio de uma sociedade burguesa, inspirado no Código Napoleônico, cujas preocupações repousavam justamente no contrato e na propriedade, para a garantia da solidez das relações patrimoniais, e na família, porém aqui pensada como um fim em si mesma.

Com a Segunda Grande Guerra, a dignidade humana foi incorporada à ordem jurídica brasileira, passando a pessoa humana, a ocupar o seu ponto central. Esse giro de valores provocou, naturalmente, um giro hermenêutico. Veio, igualmente, o fenômeno da descodificação, com a criação dos microssistemas, cujo objetivo era o de, justamente, conferir uma adequada proteção ao homem, enquanto consumidor, inquilino etc.

MOREIRA (1994), em 1994, anotou que:

\begin{abstract}
Entre as primeiras manifestações do fenômeno situa-se o aumento, notável a partir de certa época, do interesse pelos vínculos entre processo e Constituição. Não se trata de noção propriamente nova. Sabe-se de longa data que o papel do direito processual consiste, em grande parte, na concretização de promessas constitucionais. O que há de novo é a ênfase que, de algum tempo para cá, vem assumindo esse mister do pensamento jurídico brasileiro.
\end{abstract}

O fenômeno foi cunhado de constitucionalização do direito, que no escólio de BARROSO (2005):

\begin{abstract}
(...) está associada a um efeito expansivo das normas constitucionais, cujo conteúdo material e axiológico se irradia, com força normativa, por todo o sistema jurídico. Os valores, os fins públicos e os comportamentos contemplados nos princípios e regras da Constituição passam a condicionar a validade e o sentido de todas as normas do direito infraconstitucional.
\end{abstract}

Em 2002, o novel Código Civil entrou em vigor, consagrando princípios como a boa-fé objetiva e a função social, entre outros, que possibilitaram que a dignidade permeasse todo o tecido normativo infraconstitucional.

Em contrapartida, apesar dessa evolução nos comandos de direito material, o Direito Processual ainda não continha textualmente ferramentas que possibilitavam o necessário diálogo com a Constituição Federal.

Grande avanço ocorreu com a entrada em vigor do Código de 2015, que já no seu artigo $1^{\circ}$, estipulou que o processo civil será ordenado, disciplinado e interpretado conforme os valores e as normas fundamentais estabelecidos no texto Constitucional, e, no artigo $8^{\circ}$, estabelece que o 
juiz atenderá aos fins sociais, às exigências do bem comum, resguardando e promovendo a dignidade da pessoa humana.

Agora, em absoluto compasso e sintonia com o direito material, iluminando o processo como um instrumento de cidadania, destinado a promover uma sociedade livre, justa e solidária, como, aliás, anela o artigo $3^{\circ}$, I, da Constituição.

\section{A DIMENSÃO DO ACESSO À JUSTIÇA}

$\mathrm{O}$ acesso à justiça cuida de direito e garantia fundamental, esculpido no artigo $5^{\circ}$, XXXV, da Constituição, e, inclusive, encontra-se positivado também no artigo $3^{\circ}$, do Código de Processo Civil.

Trata-se de cláusula pétrea, com todas as consequências daí advindas, notadamente no que diz respeito à possibilidade de sua supressão, por força de alteração do texto normativo ou mesmo interpretação que lhe restrinja o alcance.

CAPPELLETTI (1998, p. 11/13) sublinha que

De fato, o direito ao acesso efetivo tem sido progressivamente reconhecido como sendo de importância capital entre os novos direitos individuais e sociais, uma vez que a titularidade de direitos é destituída de sentido, na ausência de mecanismos para a sua efetiva reivindicação. $\mathrm{O}$ acesso à justiça pode, portanto, ser encarado como o requisito fundamental - o mais básico dos direitos humanos - de um sistema jurídico moderno e igualitário que pretenda garantir, e não apenas proclamar os direitos de todos.

Este acesso é fundamental, sobretudo se se compreender que numa sociedade complexa,

(...) a existência de conflitos dentro de uma sociedade é algo natural, pois existindo necessidades ilimitadas e bens limitados sua aparição é inevitável (...). Pois o que não é natural nem saudável é a permanência do conflito dentro da sociedade e não sua aparição. (Carreira Alvim, 2003)

Assim, sempre haverá necessidade de que o Estado entregue ao cidadão um produto adequado: uma prestação jurisdicional célere e efetiva, capaz de, outrossim, reestabelecer a paz social.

O acesso à justiça há que ser compreendido em dimensão mais abrangente, não bastando que se garanta o acesso formal, como um simples direito de provocar o Poder Judiciário ou um direito de petição. Este, a propósito, é alvo de preocupações já antigas da doutrina (vide a propósito as ondas renovatórias de acesso à justiça, de CAPPELLETTI) e do 
legislador pátrio, conforme se vê da edição da Lei 1.060/50 (que estabelece normas para a concessão de assistência judiciária aos necessitados), bem assim do constante aparelhamento das Defensorias Públicas, das demandas coletivas etc.

Necessário que seja entendido também como a possibilidade de se atuar como protagonista na busca de uma solução à querela posta, de participar ativamente na formação do convencimento do magistrado, e notadamente o de obter um provimento jurisdicional, cunhado por ALVIM (2003) como o descesso.

O festejado autor ensina que

O problema do acesso à Justiça não é uma questão de "entrada", pois, pela porta gigantesca desse templo chamado Justiça, entra quem quer, seja através de advogado pago, seja de advogado mantido pelo Poder Público, seja de advogado escolhido pela própria parte, sob os auspícios da assistência judiciária, não havendo, sob esse prisma, nenhuma dificuldade de acesso. O problema é de "saída", pois todos entram, mas poucos conseguem sair num prazo razoável, e os que saem, fazem-no pelas "portas de emergência", representadas pelas tutelas antecipatórias, pois a grande maioria fica lá dentro, rezando, para conseguir sair com vida.

Cediço, nesta linha, que um dos grandes entraves do acesso à justiça não é o efetivo ingresso em Juízo, mas sim a obtenção de uma tutela final, que decorre de fatores variados como por exemplo a cultura altamente demandista brasileira, que assoberba o Poder Judiciário, a morosidade e até mesmo o uso (sistemático e) indevido de subterfúgios processuais, que atravancam o andamento do feito.

BARROSO (2005) lembra que "o Direito vive uma grave crise existencial. Não consegue entregar os dois produtos que fizeram sua reputação ao longo dos séculos. De fato, a injustiça passeia pelas ruas com passos firmes e a insegurança é a característica da nossa era".

Em tempo, vale trazer à colação uma importante advertência:

É certo que tanto Estado quanto sociedade não desejam o retorno da autotutela, sendo que o ordenamento jurídico hodierno admite-a somente em situações excepcionais, notadamente nas questões ligadas à direitos reais. Assim, para evitar seu retorno, deve o Estado proporcionar um efetivo acesso à justiça para a sociedade e, ainda mais, um verdadeiro descesso célere e qualitativo do próprio Poder Judiciário. (Filho e Gonçalves, 2010)

\section{A ÉTICA KANTINA}

O Brasil e, de resto, toda a humanidade, vive um período marcado por graves crises éticas. Escândalos de corrupção envolvendo os Poderes da República e as instituições públicas, 
cuja função é justamente a de garantir o bom funcionamento da máquina administrativa e proporcionar o exercício dos direitos sociais e individuais, a liberdade, a segurança, o bem-estar, o desenvolvimento, a igualdade e a justiça: Lavajato, mensalão, carne fraca. São variados os exemplos.

No âmbito das relações interpessoais não é diferente.

KANT (1986) afirma a existência de uma máxima, que consiste num princípio subjetivo do querer, asseverando que o homem, enquanto ser racional, deve se portar sempre de modo que essa máxima se torne uma lei universal. Ele procura os fundamentos de uma ética válida universalmente, que tenha como fundamento o princípio supremo da moralidade, o imperativo categórico.

Esclarece que, ainda que falte experiência sobre "as coisas do mundo", o indivíduo é capaz, com base em seus conhecimentos a priori, de reconhecer e distinguir o bom do mau, o certo do errado, o que é conforme e o que é contrário ao dever, bastando que responda à pergunta: "Podes tu querer também que a tua máxima se converta em lei universal?"(1986, p. 35)

Diz que as coisas na natureza regem-se por leis e que somente os seres racionais podem agir segundo a representação destas normas, por possuir vontade, é dizer, autonomia.

Prossegue o autor, afirmando que existem mandamentos da razão, capazes de coagir a vontade, que se expressam na forma de imperativos, expressos pelo verbo dever. Estes, por seu turno, são hipotéticos ou categóricos, sendo os primeiros representados pela necessidade de uma ação possível, como meio para alcançar outra coisa que se pretende, enquanto que os categóricos, são os que representam uma ação como necessária por si mesma.

O filósofo identifica, assim, a existência de um fundamento que serve à lei prática universal, no sentido de que a natureza racional existe como um fim em si mesma, indicando que o imperativo prático será: “Age de tal maneira que uses a humanidade, tanto na sua pessoa como na pessoa de qualquer outro, sempre e simultaneamente como fim e nunca simplesmente como meio.”(1986. p. 69)

Seguindo, afirma existir um o reino, união sistemática de diversos seres racionais submetidos a leis comuns, e que neste reino os indivíduos devem se tratar a si e aos outros como fins em si: o reino dos fins.

Ao tratar da moralidade ele fala da relação das ações com a legislação (que só possibilita o reino dos fins) e que esta deve se encontrar em todo ser racional e emanar de sua vontade baseado no princípio segundo o qual deve-se "agir somente segundo uma máxima tal 
que possa ser erigida em lei universal." A isso ele nomina de coação prática ou dever.

Kant explica a ética/moral apelando para o conceito de dever, porque o homem ser moral - não possui uma boa vontade sempre e naturalmente. $\mathrm{O}$ dever é que irá permitir que se torne boa a vontade nos seres finitos. Por sua vez, a boa vontade reside em cumprir o dever pelo respeito ao dever (e não em respeito à legalidade). A moralidade, portanto, irá dotar a vontade de uma qualidade que irá distinguir os seres humanos dos animais racionais, que agem somente de acordo com as leis da natureza. (BARRETO, 2010 , p. 50/51)

Assevera, nesta senda, que

No reino dos fins tudo tem um preço ou uma dignidade. Uma coisa que tem um preço pode ser substituída por qualquer outra coisa equivalente; pelo contrário, o que está acima de todo preço e, por conseguinte, o que não admite equivalente, é o que tem uma dignidade. (KANT, 1986, p. 77)

Propõe que a moralidade seja a única condição capaz de fazer um ser racional como um fim em si mesmo e que a autonomia, consistente na capacidade de fazer com que a vontade seja lei para si mesma, dá ao homem a possibilidade de escolha de acordo com máximas que possam se tornar leis universais.

Transportando-se o ideário Kantiano à era pós-moderna, era da ética, possível abandonar a ideia de universalização e codificação da moral, deixando a cargo do indivíduo, dotado de responsabilidade, a escolha de como agir, sempre pautado nas máximas do imperativo categórico.

\section{A ÉTICA NO PROCESSO CIVIL}

Seguindo a tendência em torno da abordagem ética do mundo pós-moderno, obviamente há que se conceber um processo civil baseado em raízes éticas.

A relevância do processo como instrumento de cidadania e de exercício da democracia participativa, é sublinhada por GUIMARÃES (2007, p. 66):

A verdadeira práxis democrática, configuradora de um autêntico Estado de Direito, reside principalmente na efetiva concretização dos direitos e garantias fundamentais e não em meras abstrações legais contidas em um texto normativo, estes direitos e garantias fundamentais, por sua vez, somente ganham vida através do mais afinado instrumento democrático: o processo.

Pela sua relevante missão enquanto instrumento de promoção de uma sociedade livre, 
justa e solidária, concretizadora dos direitos fundamentais, o processo, que tem os seus escopos jurídico, econômico e social, revela-se incompatível com comportamentos lesivos, desprovidos das mais sinceras intenções de promover o bem, e, óbvio, sob um olhar objetivo, que vá de encontro às expectativas legítimas criadas e mantidas pelos atores processuais, pois é necessário compreender a responsabilidade para com o outro.

E não há uma enumeração exaustiva de situações-tipo que impliquem falta de ética, é dizer, não há um código prescrevendo ou proibindo condutas (não exaustivamente) às partes envolvidas na relação juridico-processual.

Há, ao revés, comandos gerais e abstratos que trazem diretrizes de atuação, a exemplo dos princípios da boa-fé.

O então Min. Salvio de Figueiredo Teixera sublinhou no bojo do Resp 65906/DF, em que relator, que "o processo não é um jogo de esperteza, mas instrumento ético da jurisdição para efetivação dos direitos de cidadania."

\section{7- A SISTEMÁTICA DO CÓDIGO DE PROCESSO CIVIL}

O Digesto Processual Civil há que ser compreendido como um sistema, dotado de unidade de sentido e coerência, que, aliás, lhe é conferido pelos princípios por ele adotados.

SUNDFELD (1993, p. 137) assevera que “os princípios são as ideias centrais de um sistema, ao qual dão sentido lógico, harmonioso, racional, permitindo a compreensão de seu modo de organizar-se."

Nesta mesma trilha, ensina ROCHA (1994, p. 23) que a ordem jurídica "forma-se, informa-se e conforma-se pelos princípios adotados."

Noronha, por sua vez, registra que os princípios permitem a constante atualização do sistema, bem assim a incorporação a ele de valores culturais e sociais, verbis:

O direito é efetivamente composto por normas, como sustentado pelos positivistas, mas estas são informadas por princípios, estão imbuídas de valores, que são os valores culturais da própria sociedade. São estes que alimentam o sistema jurídico, que o impregnam e que ele deve preservar - e reproduzir. (Noronha, 1994, p. 31)

Justamente em decorrência dessa unidade sistêmica e pela missão que os princípios desempenham, enquanto espécie de amalgama, responsável por manter a coesão da ordem jurídica, que a violação a um princípio representa algo deveras censurável. 


\subsection{A boa-fé objetiva}

A boa-fé é um destes princípios, vazado em cláusula geral, positivada expressamente no artigo $5^{\circ}$, do CPC.

Com a positivação do aludido princípio, o legislador ordinário deu os contornos do novel Processo Civil, anunciando as vigas mestras de sustentação do processo, que deve se basear na ética, até porque:

(...) o processo em seu sentido social ou, como querem alguns, instrumental, é um instrumento público eficaz, legítimo e verdadeiro de realização da justiça que foi colocado à disposição das partes pelo Estado, para que elas possam buscar a prestação da tutela jurisdicional, e nenhum instrumento de justiça pode sobreviver fundado em mentira, em conduta ímproba, em má-fé, motivo pelo qual o comportamento da parte influenciará a convicção do juiz. (GUIMARÃES, 2004)

A boa-fé permite e fomenta que a ética permeie as relações jurídico-processuais, demandando que os atores pautem-se em standarts de probidade, honestidade e retidão.

Mas qual o exato alcance da boa-fé?

Trata-se de cláusula geral, dotada, pois, da plasticidade.

É concebida e estudada sob duas perspectivas: a subjetiva e a objetiva.

A primeira leva em consideração o elemento subjetivo que anima o agente. É um estado. O antônimo de má-fé.

Já a segunda, que é a referida pelo CPC, é "regra de conduta é um dever - dever de agir de acordo com determinados padrões, socialmente recomendados, de correção, lisura, honestidade, para, como veremos na exposição subsequente, não frustrar a confiança legítima da outra parte.” (Noronha, 1994, p. 136)

RIBEIRO (2004) inclusive, a define como sobreprincípio, afirmando que

Estas são as razões pelas quais a boa-fé processual é erigida à categoria de sobreprincípio processual, que se sobrepõe aos demais, por possuir um interesse público iminente, condicionando, sempre que possível, os demais princípios, e coloca a verdade como apoio e sustento da justiça, que é a base do Direito.

A doutrina (TEPEDINO, 2015) enumera as funções da boa-fé objetiva, indicando tradicionalmente a a) interpretativa, a b) restritiva do exercício abusivo de direitos e a c) criadora de deveres anexos.

O legislador ordinário não pretendeu esgotar o alcance da boa-fé, e nem poderia. Trouxe 
algumas fattispecies apenas com o propósito de ilustrar comportamentos desviados. Preferiu, entretanto, a utilização da técnica da cláusula geral, em contraposição ao estilo elegante e linear do codificador (TEPEDINO, 2005). E assim o fez para possibilitar que o juiz possa lhe dar concretude diante do caso posto.

BARROSO (2005) usa inclusive o termo plasticidade, a fim de designar uma das características das cláusulas gerais:

\footnotetext{
As denominadas cláusulas gerais ou conceitos jurídicos indeterminados contêm termos ou expressões de textura aberta, dotados de plasticidade, que fornecem um início de significação a ser complementado pelo intérprete, levando em conta as circunstâncias do caso concreto.
}

Melhor que assim seja, afinal não há como elaborar um conceito de ética universalmente válido, muito menos positivá-lo em texto normativo.

Demais disso, a análise sobre um comportamento possivelmente violador da boa-fé não deve ser entregue a uma agência supraindividual. Não há que ser heterônomo. Deve, ao revés, partir do próprio indivíduo, a chamar a sua responsabilidade nas suas relações para com o outro e na chamada lei universal.

Sabe-se que, vivendo em comunidade, as interações são inevitáveis. Sabe-se que num processo de traço marcadamente adversarial, o comportamento de uma parte gera na outra uma expectativa legítima, que é tutelada pela ordem jurídica.

Não por outra razão que a boa-fé surge como um parâmetro para interpretar situações, restringir direitos e criar deveres.

Sua proteção pela ordem normativa tem por escopo garantir a segurança jurídica, ou, no escólio da doutrina:

\footnotetext{
A boa-fé pode ser reconduzida à segurança jurídica, na medida em que é possível reduzi-la dogmaticamente à necessidade de proteção à confiança legítima - que constitui um dos elementos do princípio da segurança jurídica - e de prevalência da materialidade no tráfego jurídico. (Marinoni, 2018)
}

\subsection{O assédio processual}

Os direitos subjetivos positivados na ordem normativa devem ser exercidos em absoluta consonância com os ditames constitucionais, até por conta da supremacia constitucional, sempre tendo em vista os princípios e objetivos fundamentais da República Federativa Brasileira.

Impossível conceber que estes direitos sejam gozados de forma desviada ou com 
propósitos escusos, caso em que se estaria diante de flagrante ruptura com a própria sistematicidade da ordem jurídica.

Não por outra razão que o artigo 187, do Código Civil consagrou a teoria do abuso do direito, estabelecendo que constitui ilícito o exercício de um direito de forma a exceder manifestamente os limites impostos pelo seu fim econômico ou social, ou pela boa-fé ou pelos bons costumes.

MIRAGEM (2013) explica que

Reforça assim, o conceito de relatividade dos direitos subjetivos, não apensa afirmando que a vontade do titular não os controla completamente, mas igualmente caracterizando os limites dessa vontade de acordo com os fins para os quais se conceberam tais direitos.

A autonomia privada encontra, pois, limites impostos pelas balizas esculpidas no já mencionado artigo 187.

O raciocínio há que ser transportado ao campo do direito processual, afinal o exercício do (sagrado) direito de ação, de situações ou faculdades processuais, há que ser feito em consonância com o seu fim econômico e social, a boa-fé e os bons costumes.

O comportamento ético, honesto, probo, que leva em consideração o outro, em busca de uma decisão adequada e, acima de tudo, justa. É pressuposto do processo, enquanto instrumento de cidadania, incompatível com qualquer tipo de abuso.

A advertência sempre pertinente no sentido de que

É importante não confundir a impossibilidade da exclusão da tutela jurisdicional, com o controle realizado pelo juiz para coibir o abuso do exercício do direito de ação. $\mathrm{O}$ processo é das partes, e não do autor. O direito de ação não pode ser irrestrito, e deve ser exercido em respeito à parte contrária, notadamente no caso de não ser molestada naquelas situações em que a demanda for absolutamente inviável. (Wambier, 2015)

Como se nota, a prestação jurisdicional, dada a sua relevante missão na concretização de direitos, em que pese se tratar de direito público subjetivo, há que se compatibilizar com os ditames constitucionais, não se tratando, como pode parecer, de singelo alvedrio do proponente. Este deve buscar em Juízo uma sincera e legítima pretensão e, portanto, guiar-se pela boa-fé.

O abuso merece, outrossim, ser encarado de forma dura, a fim de desestimular aventuras irresponsáveis, de caráter vindito ou mesmo protelatório. O processo não pode se prestar a esta tarefa.

TARUFFO (2017, p. 79), ao tratar mais amiúde sobre abuso do processo, após reconhecer as dificuldades de sua exata conceituação, esclarece que 
(...) diz respeito às hipóteses em que um sujeito inicia e prossegue um processo não com o fim de obter do juiz a resolução de uma controvérsia ou de obter o reconhecimento de um direito seu (que seria o escopo próprio do processo), mas com o escopo de prejudicar o adversário ou de qualquer forma criar-lhe problemas ou provocar-lhe consequências negativas.

Ainda na quadra do abuso, CAMACHO e CAMBI (2017) conceitam o assédio processual categoria do abuso de direito, como

(...) uma modalidade de assédio moral, mas com atuação limitada à relação processual: o assediador almeja causar abalo psicológico à parte contrária ou a ambas as partes (se partir do juiz), por intermédio da prática de reiteradas condutas processuais voltadas a obstar a efetivação de seus direitos. (Camacho e Cambi, 2017)

A boa-fé objetiva, como se nota, é capaz de fornecer parâmetros adequados à avaliação da situação, notadamente por meio de sua função restritiva, que Tepedino (2015) sublinha como

No que tange à segunda função indicada, a boa-fé atua como limite negativo ao exercício de direitos, de modo a impedir, no âmbito dos contratos, o exercício irregular ou abusivo de posições contratuais. Tal função da boa-fé foi incorporada no artigo 187 do novo Código Civil, que inclui a boa-fé com um dos parâmetros do controle de abusividade.

A boa-fé, nessa perspectiva, tem por função, restringir condutas. Justamente como forma de tutela da expectativa legítima, decorrência dos deveres laterais por ela impostos.

O Egrégio Tribunal da Cidadania tem proferido algumas decisões invocando a boa-fé objetiva e a própria ética, para reconhecer condutas abusivas e efetivamente punir os litigantes.

Cita-se, por exemplo, o Resp 978.337, em que o Superior Tribunal de Justiça aplicou multa à União por aviar recurso com propósito manifestamente protelatório. Ficou consignado no voto do Ministro Mauro Campbell Marques que:

A Constituição da República vigente preconiza de forma muito veemente a necessidade de resolver de forma célere as questões submetidas ao Poder Público (arts. $5^{\circ}$, inc. LXXVIII, e 37, caput), uma vez que essas demandas dizem com as vidas das pessoas, com seus problemas, suas angústias e suas necessidades. A seu turno, a legislação infraconstitucional, condensando os valores e princípios da Lei Maior, é pensada para melhor resguardar direitos, e não para servir de mecanismo subversivo contra eles.

Em tempos de severas críticas ao Código de Processo Civil brasileiro, é preciso pontuar que pouco ou nada adiantará qualquer mudança legislativa destinada a dar agilidade na apreciação de processos se não houver uma revolução na maneira de encarar a missão dos Tribunais Superiores e do Supremo Tribunal Federal.

Enquanto reinar a crença de que esses Tribunais podem ser acionados para funcionarem como obstáculos dos quais as partes lançam mão para prejudicar o andamento dos feitos, será constante, no dia a dia, o desrespeito à Constituição. Como se não bastasse, as consequências não param aí: aos olhos do povo, essa desobediência é fomentada pelo 
Judiciário, e não combatida por ele; aos olhos do cidadão, os juízes passam a ser inimigos, e não engrenagens de uma máquina construída unicamente para servi-lo.

É por isso que, enfrentando situações como a presente, na falta de modificação no comportamento dos advogados (públicos ou privados) - que seria, como já dito, o ideal , torna-se indispensável que também os magistrados não fiquem inertes, que também eles, além dos legisladores, tomem providências, notadamente quando o próprio sistema já oferece arsenal para tanto. É caso de aplicar o art. 538, p. ún., do Código de Processo Civil.

Estes comportamentos abusivos infelizmente não são novidade no Brasil, acabando por retirar do jurisdicionado a esperança última que reside no processo enquanto ferramenta de obtenção do bem da vida, contribuindo, demais disso, ao descrédito do Poder Judiciário.

O processo não pode ser guiado pela esperteza, tampouco deve a crença na justiça desaparecer.

Do ponto de vista econômico, a (equitativa e) adequada distribuição do bem da vida, objeto de litigio, há que ser feita de modo célere. O custo/benefício de um processo moroso sempre é sopesado pelo litigante astuto, por isso a importância de um combate recrudescido ao comportamento inadequado.

Já há muito discute-se a aplicação do instituto da contempt of court do direito anglosaxão e que é violador da ética processual, chegando ARANKEN DE ASSIS (2003), a afirmar que "o individualismo e a despreocupação social imperam no processo civil brasileiro."

Mais recentemente, a Ministra Nancy Andrighi reconheceu situação de assédio processual, "o ajuizamento de sucessivas ações judiciais, desprovidas de fundamentação idônea e intentadas com propósito doloso, pode configurar ato ilícito de abuso do direito de ação ou de defesa, o denominado assédio processual.” ( REsp 1817845/MS)

Colhe-se de seu voto que

(...) em virtude das nossas raízes romano-germânicas e de civil law, parece ser sempre necessário que a lei reconheça, prévia e expressamente, a ilicitude do ato abusivo e a possibilidade de puni-lo para que se cogite de examiná-lo nos conflitos que diariamente são submetidos ao Poder Judiciário, como se os deveres da boa-fé, da ética e da probidade não estivessem presentes no tecido social e, consequentemente, como se não fossem ínsitos ao direito.

O processo há que ser guiado, pois, pela ética e a violação destas balizas constitui ruptura sistêmica, demandando severas providências, já que segundo BANDEIRA DE MELLO (2005, p. 883):

Violar um princípio é muito mais grave do que transgredir uma norma. A desatenção ao princípio implica ofensa não apenas a um específico mandamento obrigatório mas a 
todo o sistema de comandos. É a mais grave forma de ilegalidade ou inconstitucionalidade, conforme o escalão do princípio atingido, porque representa insurgência contra todo o sistema, subversão de seus valores fundamentais (...)

\section{CONCLUSÃO}

Viver em comunidade traz ao ser humano inúmeras comodidades, exigindo, em contrapartida, comportamentos (positivos e negativos), afinal, mantendo contato com terceiros e estabelecendo interações sociais, há que respeitar a confiança que se é mutuamente depositada, a fim de garantir o próprio tráfego jurídico.

Não é possível cruzar um semáforo em segurança, sem confiar que os demais usuários da via pública também respeitarão as regras de trânsito, justamente porque, apesar da existência de normas pré-definidas, acredita-se que elas serão voluntariamente cumpridas.

A tutela da confiança, feita (também) por meio da boa-fé objetiva, é necessária a uma adequada prestação jurisdicional, que jamais poderá ser concebida como justa, célere e efetiva, sem o comportamento ético de seus atores.

Não há um rol exaustivo, tipificando as condutas que vulneram a boa-fé. A cláusula geral da boa-fé impõe às partes um comportamento honesto, probo, sem entretanto, delinear os seus termos pormenorizadamente.

Exatamente como Kant concebeu: o comportamento ético deve partir do próprio indivíduo, com base na cunhada lei universal. Não se delegou a um experto a tarefa de desenhar o conceito de ética, muito menos estão codificadas exaustivamente condutas e comportamentos, prontos como que numa prateleira.

A ética se materializa no processo civil pós-moderno por meio da boa-fé. Aos atores processuais cabe a tarefa de pautar-se de acordo com padrões de retidão, sempre tendo em vista a expectativa (ou a possibilidade) de que a máxima se torne uma lei universal.

A cláusula da boa-fé fornece parâmetros hermenêuticos, limita direitos e cria deveres anexos, tudo em nome desta ética. Pode-se dizer, nesta ordem de ideias, que o exercício dos direitos subjetivos não é absoluto, encontrando limites na boa-fé, conforme apregoa o artigo 187, do Código Civil. Não menos importante são os deveres laterais que ela endossa, tudo com a finalidade de proteger a segurança e a confiança.

No âmbito do processo civil, o abuso de situações processuais pode ser notado em situações como o abuso processual, exercido com a propositura de demandas temerárias, das defesas heterotópicas etc. Há que ser combalida porque em franco descompasso com a boa-fé, 
com o comportamento ético que se espera dos atores processuais.

A conduta censurada não está prevista textualmente em códigos. Não há um terceiro informando qual comportamento é permitido e qual comportamento é vedado. Extrai-se pela sua contrariedade aos preceitos morais, considerando a responsabilidade de um para com o outro.

A ordem jurídica deve combatê-la como forma de tutelar a confiança. Para poder entregar ao jurisdicionado uma tutela adequada e tempestiva, livre de embaraços indevidos. E a boa-fé se torna, neste particular, um referencial à interpretação da situação posta, à limitação do acesso (indiscriminado e indevido) à justiça, coibindo dilações indevidas.

Rememora-se que o acesso à justiça compreende também o descesso, é dizer, a saída, porém de modo justo, célere e efetivo, com um provimento de mérito. Um descesso digno, que não se encerra num provimento precário, exercido por meio de técnicas processuais que tutelam a urgência ou a evidência, sem produzir o trânsito em julgado.

Neste contexto, a boa-fé emerge como importante ferramenta à proteção ao processo (acesso à justiça), e ao combate de situações processuais abusivas, que devem ser rechaçadas e punidas a contento em prol de uma adequada prestação jurisdicional.

\section{REFERÊNCIAS}

ASSIS, Araken de. O contempt of court no direito brasileiro. 2003. Disponível em http://www.abdpc.org.br/artigos/artigo6.htm. Acesso em 04/12/2019.

BARBOSA MOREIRA, José Carlos. Os novos rumos do processo civil brasileiro. Revista 6, da Academia Brasileira de Letras Jurídicas. 1994. Disponível em http://www.ablj.org.br/revistas/revista6/revista6\%20\%20JOS\%C3\%89\%20CARLOS\%20BARB OSA\%20MOREIRA\%20-

\%200s\%20Novos\%20Rumos\%20do\%20Processo\%20Civil\%20Brasileiro.pdf. Acesso em $02 / 12 / 2019$.

BARRETTO, Vicente de Paulo. Notas Kantianas sobre o Direito. In O fetiche dos direitos humanos. Rio de Janeiro: lúmen Iuris, 2010. Disponível em https://www.academia.edu/27186450/BARRETO_Vicente._O_fetiche_dos_direitos_humanos?a uto=download.

BARROSO, Luiz Roberto. Neoconstitucionalismo e constitucionalização do direito. $O$ triunfo tardio do direito constitucional no Brasil. 2005. Disponível em http://www.luisrobertobarroso.com.br/wp- 
content/uploads/2017/09/neoconstitucionalismo_e_constitucionalizacao_do_direito_pt.pdf. Acesso em 27/11/2019.

BRASIL. SUPERIOR TRIBUNAL DE JUSTIÇA. EDcl no AgRg no REsp 978.337/GO. PROCESSUAL CIVIL. EMBARGOS DE DECLARAÇÃO COM CARÁTER INFRINGENTE. INEXISTÊNCIA DE VÍCIOS A SEREM SANADOS. IMPOSSIBILIDADE DE RECONHECER A INFRINGÊNCIA. NÍTIDO CARÁTER PROTELATÓRIO. APLICAÇÃO DO ART. 538, P. ÚN., DO CPC. (ADMINISTRATIVO. AGRAVO REGIMENTAL. RESPONSABILIDADE CIVIL DO ESTADO. DANOS MORAIS. TORTURA. REGIME MILITAR. IMPRESCRITIBILIDADE.) EMBARGANTE: UNIÃO, EMBARGADO: MARIA GOMES DOS SANTOS E OUTROS. EDcl no AgRg no REsp 978.337/GO, Rel. Ministro MAURO CAMPBELL MARQUES, SEGUNDA TURMA, julgado em 09/06/2009, DJe 23/06/2009.

Disponível

em https://scon.stj.jus.br/SCON/jurisprudencia/toc.jsp?livre=ENQUANTO+REINAR+A+CREN\%C 7A+DE+QUE+ESSES+TRIBUNAIS \& processo $=1138484 \& b=A C O R \&$ thesaurus $=J U R I D I C O \&$ $\mathrm{p}=$ true. Acesso em 09/12/2019.

BRASIL. Superior Tribunal de Justiça. TJ. REsp 65.906/DF. PROCESSO CIVIL. INTIMAÇÃO PELA IMPRENSA. AUSENCIA DO NOME DO NOVO PATRONO DA PARTE. QUATRO INTIMAÇÕES POSTERIORMENTE ENDEREÇADAS AO RECORRIDO. CONSTANCIA NESSAS PUBLICAÇÕES DOS NOMES CORRETOS DE AMBAS AS PARTES E DE SEUS PATRONOS. SUSCITAÇÃO DA NULIDADE PELA RECORRENTE APENAS QUANDO PUBLICADA INTIMAÇÃO COMUM AS DUAS PARTES. PRECLUSÃO. ART. 245, CPC. PECULIARIDADES DO CASO CONCRETO. PROCESSO COMO INSTRUMENTO ETICO. RECURSO DESACOLHIDO. RECORRENTE: ENCOL S/A ENGENHARIA COMÉRCIO E INDÚSTRIA, RECORRIDO: MANOEL DE SOUZA. Rel. Ministro SÁLVIO DE FIGUEIREDO TEIXEIRA, QUARTA TURMA, julgado em 25/11/1997, DJ 02/03/1998, p. 93. Disponível https://scon.stj.jus.br/SCON/jurisprudencia/toc.jsp?processo $=65906 \& b=A C O R \&$ thesaurus=JUR IDICO\&p=true . Acesso em 09/12/2019.

BRASIL. SUPERIOR TRIBUNAL DE JUSTIÇA. REsp 1817845/MS. CIVIL E PROCESSUAL CIVIL. AÇÃO DE REPARAÇÃO DE DANOS MATERIAIS E MORAIS. OMISSÃO E OBSCURIDADE. INOCORRÊNCIA. FUNDAMENTAÇÃO SUFICIENTE. QUESTÃO DECIDIDA. ABUSO DO DIREITO DE AÇÃO E DE DEFESA. RECORRENTES: ALBERTO JORGE MUNIZ E OUTROS, RECORRIDO: CELSO IZIDORO ROTTILLI. Rel. Ministro PAULO DE TARSO SANSEVERINO, Rel. p/ Acórdão Ministra NANCY ANDRIGHI, TERCEIRA TURMA, julgado em 10/10/2019, DJe 17/10/2019. Disponível em https://scon.stj.jus.br/SCON/jurisprudencia/toc.jsp?processo=1817845\&b=ACOR\&thesaurus=J URIDICO\&p=true. Acesso em 09/12/2019.

BREGA FILHO, Vladimir e GONÇAVES, José Vinicius Corrêa. Descesso à justiça como fator $\begin{array}{lllll}\text { de inclusão } & \text { social. } & 2010 . & \text { Disponível } & \text { em }\end{array}$ http://www.publicadireito.com.br/conpedi/manaus/arquivos/anais/fortaleza/3055.pdf. Acesso em 27/11/2019.

CAMACHO, Matheus Gomes e CAMBI, Eduardo. Acesso (e descesso) à justiça e assédio 
processual. Revista Jurídica da Escola Superior de Advocacia da OAB-PR. Ano 2, número 1, abril de 2017.

CAMBI, Eduardo. Neoconstitucionalismo e neoprocessualismo: direitos fundamentais, politicas públicas e protagonismo judiciário. 2 ed. São Paulo: Revista dos Tribunais, 2011.

CAPPELLETI, Mauro. Acesso à Justiça. Porto alegre: Fabris, 1988.

CARREIRA ALVIM, J. E. Justiça: Acesso e Descesso. 2003. Disponível em http://www.egov.ufsc.br/portal/sites/default/files/anexos/17206-17207-1-PB.htm. Acesso em 27/11/2019.

CNJ. Justiça em números 2019. Disponível em https://www.cnj.jus.br/wpcontent/uploads/conteudo/arquivo/2019/08/justica_em_numeros20190919.pdf . Acesso em 09/12/2019.

FGV DIREITO SP. Relatório ICJ Brasil. $1^{\circ}$ semestre/2017. Disponível em http://bibliotecadigital.fgv.br/dspace/bitstream/handle/10438/19034/Relatorio-

ICJBrasil_1_sem_2017.pdf?sequence=1\&isAllowed=y. Acesso em 09/12/2019.

GOMES, Mário Soares Caymmi. O direito na mudança paradigmática da pós-modernidade. Revista de informação legislativa, v. 47, n. 188, p. 191-207, out./dez. 2010. Disponível em http://www2.senado.leg.br/bdsf/handle/id/198730. Acesso em 08/12/2019.

GUIMARÃES. Darci Ribeiro. Da tutela jurisdicional às formas de tutela. Porto Alegre: Livraria do Advogado Editora, 2010.

O papel do processo na construção da democracia: para uma nova definição da democracia participativa. Revista Brasileira de Direito Processual - RDBPro. Ano 15, n. 59, 2007. Belo Horizonte: Forum 2007.

O sobreprincípio da boa-fé processual como decorrência do comportamento da parte em juízo. Revista da AJURIS, Porto Alegre, v. 31, n. 95, p. 71/78, jul/set. 2004.

HESSE, Konrad. Elementos de Direito Constitucional da República Federal da Alemanha. 20 ed. alemã. Tradução de Luis Afonso Heck. Porto Alegre:Sergio Antonio Fabris Editor, 1998.

KANT, Immanuel. Fundamentação da Metafísica dos Costumes. Tradução de Paulo Quintela. Lisboa: Edições 70, 1986.

MARINONI, Luiz Guilherme et. al. Código de processo civil comentado (ebook). 4 ed. São Paulo: Thomson Reuters Brasil, 2018.

MELlO, Celso Antônio Bandeira de. Curso de Direito Administrativo. 18 ed. São Paulo: 
Malheiros, 2005.

MIRAGEM, Bruno. Abuso do direito (livro eletrônico): ilicitude objetiva e limite ao exercício de prerrogativas jurídicas no direito privado. 1 ed. São Paulo: Editora Revista dos Tribunais, 2013.

MITIDIERO, Daniel. Estado Constitucional e Controle de Constitucionalidade no Brasil. Processo Civil e Estado Constitucional. Porto Alegre: Livraria do Advogado Editora, 2007.

NERY JUNIOR, Nelson. Princípios do processo na Constituição Federal: processo civil, penal e administrativo. 10 ed. São Paulo: Editora Revista dos Tribunais, 2010.

NORONHA, Fernando. O direito dos contratos e seus princípios fundamentais. São Paulo: Saraiva, 1994.

ROCHA, Cármen Lucia Antunes. Princípios Constitucionais da Administração Pública. Belo Horizonte: Del Rey, 1994.

SILVA, Paulo Fernando da. Conceito de ética na contemporaneidade segundo Bauman (recurso eletrônico). São Paulo: Cultura Acadêmica, 2013.

SUNDFELD, Carlos Ari. Fundamentos de direito público.2 ed. São Paulo: Malheiros, 1993.

TARUFFO, Michele. Ensaios sobre o processo civil: escritos sobre o processo e justiça civil. Porto Alegre: Livraria do Advogado, 2017.

TEPEDINO, Gustavo. Notas sobre os princípios contratuais e a teoria dos contratos. 2015. Disponível em https://www.academia.edu/36120524/Notas_sobre_os_princ\%C3\%ADpios_contratuais_e_a_rela tividade_dos_contratos. Acesso em 09/12/2019.

WAMBIER, Teresa Arruda Alvim et. al coordenadores. Breves comentários ao código de processo civil (livro eletrônico). 1 ed. São Paulo: Ed. Revista dos Tribunais. 